\title{
悪性腫瘍切除後の口腔領域即時再建手術に関する検討 一大胸筋皮弁による40症例
}

\author{
大村進 - 石川好美 - 増田元三郎 - 遠藤 盛 \\ 小野繁・藤田浄秀
}

\section{Immediate reconstruction in head and neck cancer: Analysis on 40 pectoralis major myocutaneous flaps}

\author{
Susumu Ohmura - Yoshimi Ishikawa - Genzaburo Masuda \\ Moritaka Endo - Shigeru Ono - Kiyohide FujrTa
}

\begin{abstract}
Forty patients who underwent transposition of pectoralis major myocutaneous flap for the immediate reconstruction of defects after resection of head and neck cancer were reviewed. In our series, 18 patients experienced 30 complications related to flap usage. Those were 2 partial flap necrosis, 9 marginal flap necrosis, 6 suture line separations and 13 orocutaneous fistulas. Although most complications were minor and healed with local wound care, 5 orocutaneous fistulas associated with infection around the mandibular bone required removal of reconstruction plate, wire and grafted bone to achieve healing of fistulas. There were 30 patients that resulted in acceptable disability. However, 6 patients could not take peroral feedings and 4 patients could not successfully take an adequate amount of oral feedings as a result of persistent aspiration.

There is no question that the pectoralis major myocutaneous flap has various advantages as a one-stage reconstructive technique. However, recent reports have suggested that the incidence of complications is far greater than previously considered. In our series, overall incidence $(45 \%)$ was also high as described above.

Of 40 patients, 27 received preoperative irradiation which ranged from 40 to $250 \mathrm{~Gy}$ and 30 patients received preoperative chemotherapy. Based on our experiences, we concluded that pathological changes of mandibular bone induced by irradiation was, at least in part, related to the postoperative infections which preceded the formation of orocutaneous fistulas.

Recent analysis on the vascular system of the skin has revealed that there are few cutaneous branches derived from thracoacrominal artery in the chest skin. Thus, we believe this anatomical character is closely related to the high incidence of complications.

10 patients were treated with salvage operation combined with planned perioperative irradiation and chemotherapy, It seemed likely that the immediate reconstruction with pectoralis major myocutaneous flap contributed to the development of such a combination therapy in the management of advanced head and neck cancer.
\end{abstract}

Key words: immediate reconstruction (即時再廷), pectoralis major myocutaneous flap (大胸 筋皮升)，head and neck cancer (頭頙部瘦)

横浜市立大学医学部口腔外科学諈座 （主任：藤田浄秀教授）

Department of Oral and Maxillofacial Surgery,
School of Medicine, Yokohama City University (Chief: Prof. Kiyohide Fujita)

受付日: 平成元年 4 月 20 日 
表 1 最近 7 年間に用いられた遠 隔皮弁

\begin{tabular}{lr}
\hline 阏皮弁 & \\
大胸笳皮弁 & 42 \\
広背笳皮弁 & 6 \\
胸鎖乳突筋皮弁 & 3 \\
薄笳皮弁 & 1 \\
皮 弁 & \\
D-P 皮弁 & 12 \\
額皮弁 & 1 \\
前腕皮弁 & 1 \\
\hline 計 & 66 \\
\hline
\end{tabular}

は じめに

頭頸部癌治療の理想が放射線, 化学療法による保存的 治療にあることはいらをでもない，しかしながら，現状 では根治的治療のために頭頸部領域の広範な切除を余儀 なくされるロ腔癌症例は少なくない.

外科的な治療により腫瘍は切除され，生命は救われた としても, 術後に顔貌の醜形と, 生理的な食事の経口摄 取, 会話によるコミュニケーションなど，人間にとって 根元的とも言光る機能に高度な障害が残ることもまれで なく, 患者の受ける精神的, 肉体的苦痛は計り知れな (1). したがって手術後に予想される機能障害と形態変 化を可能な限り少なくするために，再建手術手技の検討 は, 進展した口腔癌の外科的治療にとって重要な課題の 一つと思われる。

今日までに頭頸部領域の再建のために各種の皮弁筋皮 弁が考案され，多くの臨床応用が報告されてきた。 それ らの報告からは, 従来では手術が困難とされていた進展 症例に対しても, 再建外科の進歩により確かに外科的治 療が可能となったことが宿われる。しかしながらいまだ に形態，機能の回復はともに十分とはい方ず，さらに， 症例によっては皮弁の壞死や感染，皮店口腔瘦の形成， 皮弁採取部の審美的障害, 機能障害など新たな合併症の 発生が問題となっている，症例に応して使用する皮弁， 筋皮弁を適切に選択し，術後の合併症の発生を未然に防 止するためには，それぞれの再建手術手技の持つ長所と 短所を十分把握し, 改善工夫してゆくことが重要と思わ れる。今回当科に打いて施行された口腔領域悪性腫瘍切 除後の大胸筋皮弁による即時再建手術 40 症例を臨床的に 検討し, 大胸筋皮弁の特徴, 再建手術の術後経過を左右 する種々の要因関し，若干の知見を得たので報告す る.
表 2 対象症例

\begin{tabular}{|c|c|c|c|c|c|}
\hline $\begin{array}{l}\text { 症例 } \\
\text { No. }\end{array}$ & 性 & 年齢 & 原発部位 & 組織型 & $\begin{array}{l}\text { TNM } \\
\text { 分 類 }\end{array}$ \\
\hline 1 & 男 & 69 & 下顎歯肉 & $\mathrm{SCC}$ & 二次症例 \\
\hline 2 & 男 & 69 & 口底 & $\mathrm{SCC}$ & T4N0 \\
\hline 3 & 男 & 48 & 頓粘膜 & $\mathrm{SCC}$ & 二次症例 \\
\hline 4 & 女 & 49 & 口底 & MET & 二次症例 \\
\hline 5 & 女 & 73 & 下顎歯肉 & $\mathrm{SCC}$ & 二次症例 \\
\hline 6 & 女 & 73 & 下顎歯肉 & $\mathrm{SCC}$ & T4N0 \\
\hline 7 & 男 & 46 & 口底 & $\mathrm{SCC}$ & 二次症例 \\
\hline 8 & 女 & 63 & 舌 & $\mathrm{SCC}$ & T4N0 \\
\hline 9 & 男 & 61 & 舌 & $\mathrm{SCC}$ & 二次症例 \\
\hline 10 & 男 & 56 & 舌 & $\mathrm{SCC}$ & 二次症例 \\
\hline 11 & 男 & 61 & 口底 & $\mathrm{SCC}$ & 二次症例 \\
\hline 12 & 男 & 50 & 舌 & SCC & 二次症例 \\
\hline 13 & 男 & 36 & 舌 & SCC & T3N2 \\
\hline 14 & 男 & 71 & 口底 & $\mathrm{SCC}$ & 二次症例 \\
\hline 15 & 男 & 60 & 舌 & $\mathrm{SCC}$ & 二次症例 \\
\hline 16 & 男 & 57 & 舌 & $\mathrm{SCC}$ & T4N0 \\
\hline 17 & 男 & 61 & 舌 & $\mathrm{SCC}$ & 骨髄炎 \\
\hline 18 & 女 & 78 & 下顎㧘肉 & $\mathrm{SCC}$ & T4N1 \\
\hline 19 & 男 & 78 & 下顎歯肉 & $\mathrm{SCC}$ & T4N1 \\
\hline 20 & 女 & 62 & 下顎粎肉 & $\mathrm{SCC}$ & T3N1 \\
\hline 21 & 男 & 63 & 下顎歯肉 & $\mathrm{SCC}$ & T4N2 \\
\hline 22 & 男 & 60 & 口底 & $\mathrm{ACC}$ & 二次症例 \\
\hline 23 & 女 & 55 & 舌 & $\mathrm{SCC}$ & 二次症例 \\
\hline 24 & 女 & 47 & 舌 & $\mathrm{SCC}$ & 二次症例 \\
\hline 25 & 男 & 57 & 口底 & $\mathrm{ACC}$ & $\mathrm{T} 4 \mathrm{~N} 1$ \\
\hline 26 & 女 & 39 & 舌 & $\mathrm{SCC}$ & T3N2 \\
\hline 27 & 男 & 49 & 口底 & SCC & T4N0 \\
\hline 28 & 男 & 50 & 口底 & $\mathrm{SCC}$ & T4N3 \\
\hline 29 & 男 & 65 & 軟口蓋 & $\mathrm{SCC}$ & 二次症例 \\
\hline 30 & 男 & 57 & 軟口蓋 & SCC & $\mathrm{T} 2 \mathrm{~N} 1$ \\
\hline 31 & 男 & 69 & 口陕咽頭 & $\mathrm{SCC}$ & T4N0 \\
\hline 32 & 女 & 76 & 舌 & $\mathrm{ACC}$ & T3N2 \\
\hline 33 & 男 & 63 & 下顎歯肉 & $\mathrm{SCC}$ & T4N2 \\
\hline 34 & 男 & 46 & 上顎歯肉 & SCC & 二次症例 \\
\hline 35 & 男 & 49 & 口陕咽頭 & $\mathrm{SCC}$ & 二次症例 \\
\hline 36 & 男 & 56 & 舌 & $\mathrm{SCC}$ & T4N2 \\
\hline 37 & 男 & 60 & 軟口蓋 & $\mathrm{SCC}$ & 二次症例 \\
\hline 38 & 男 & 74 & 口底 & $\mathrm{SCC}$ & T2N0 \\
\hline 39 & 男 & 56 & 口底 & $\mathrm{SCC}$ & T4N2 \\
\hline 40 & 男 & 60 & 口底 & $\mathrm{SCC}$ & T2N3 \\
\hline
\end{tabular}

$\mathrm{SCC}$ : 扁平上皮癌, $\mathrm{ACC}$ : 腺様軎胞㢞, MET : 粘 表皮腫 

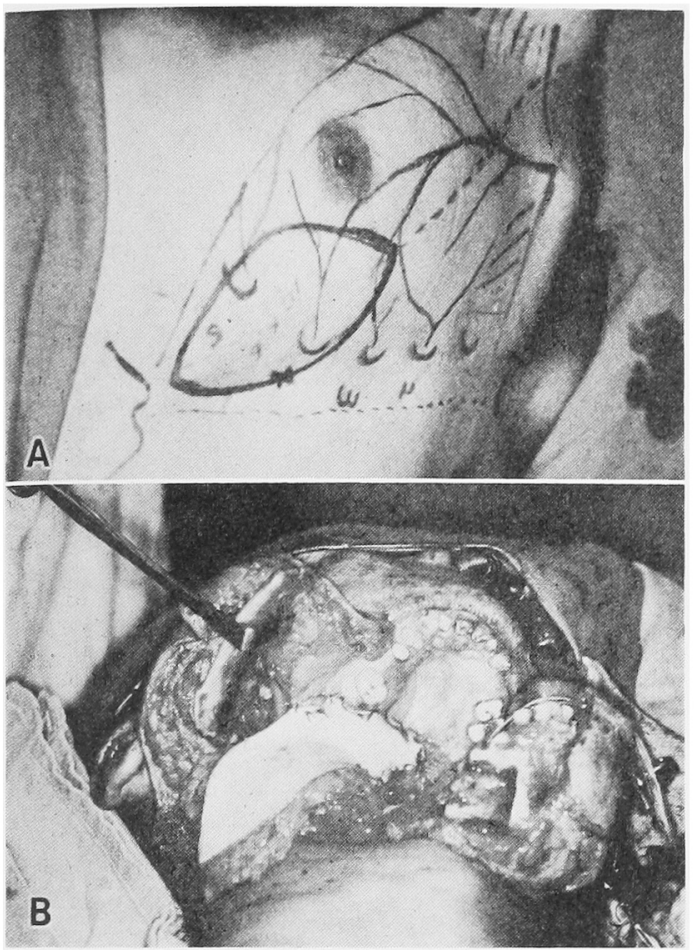

写真 1 症例 No. 30

$\mathrm{A}$ ：大胸筋皮弁採取デザイン

B：口聜内の再建

\section{対 象 症 例}

1982年 1 月より1988年12月までの 7 年間に，当科に拈 いて悪性属湯切除後に施行された遠隔皮弁を用いた再建 手術は66症例で，その内訳は大胸筇皮异42例，広背筋皮 升 6 例（有荎 4 例，遊離 2 例)，胸鎖乳突筋皮弁 3 例， 遊離薄筋皮升 1 例，D-P 皮升 12例，前腕皮弁 1 例，額 皮弁 1例であった（表1）。そのうち 1988年 9 月までに 施行した大胸筋皮弁の 40 症例について検討を行った。

症例の内訳男30例，女10例，男:女， $=3: 1$, 年龄 分布は最小 36 歳 (男), 最高78歳 (男, 女各 1 名), 30 歳 代 2 例， 40 歳代 7 例，50歳代 9 例，60歳代15例，70歳代 7 例，平均年㱓 59 藏であった（表 2 ）。腫瘍の組織型は 澼平上皮癌36例，腺様庭胞癌 3 例，粘表皮腫 1 例で，発 生部位別では舌13例，口底12例，下顎歯肉 8 例，上䫚歯 肉 1 例，軟口葐 3 例，口峡咽頭 3 例であった（表 2 ）。

TNM 分類 (UICC 1978 分類) からみた 腫瘍の進展度 は T4 14例, T3 4 例， T2 3 例で,これらの症例の Stage 分類は S IV 19例, S III 1 例, S II I例であった (表 2). その他の症例は当科，他科，他施設における二 次症例18例と放射線性下顠骨骨䯣炎の1例であった（表
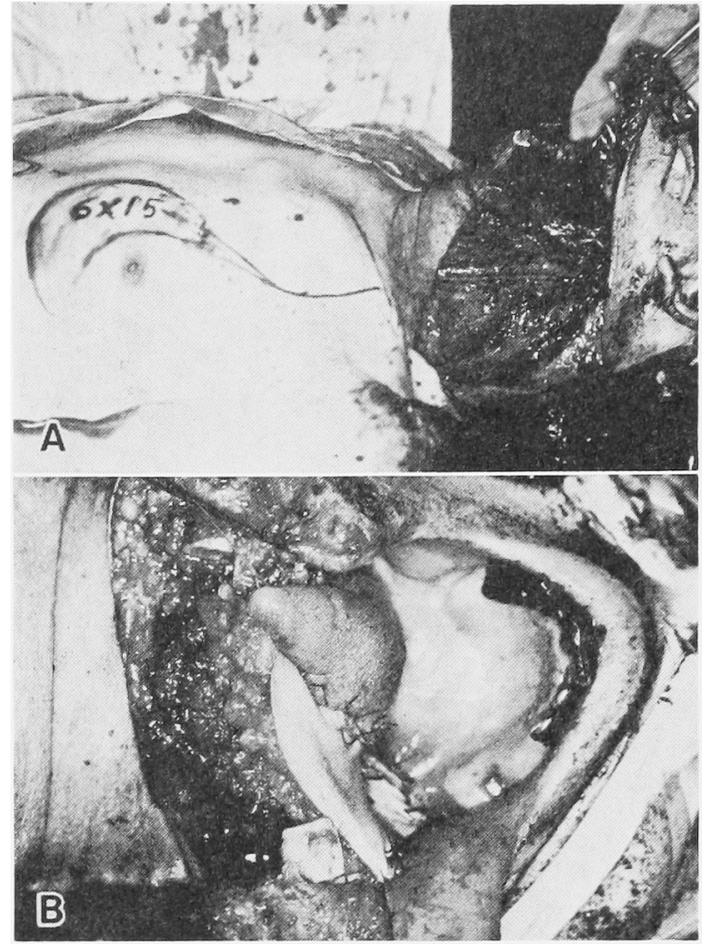

写真 2 症例 No. 25

A：大䀲筋皮弁の採取デザィン

B : 口腔内の再建

2).

\section{手術方 法}

皮弁の採取のためのデザインの設定は，原則として Ariyan の方法 ${ }^{2,3)}$ に従い，肩甲骨肩峰突起と胸骨剣状突 起を結ぶ線を皮弁の長軸の基準線として用いた（写真 1).しかし症例ごとにデザインの細部は様々で，皮弁 の遠位端を Ariyan の基準線より外側に設定し, 乳頭の 外下方より採取した症例多多かった（写真 $2 ， 3$ ）. 症例 No. 5 は舌口底の再建に連続し，下唇，才トがイの再建 をするために皮島の遠位端を第八肋骨下端の腹直筋膜上 に設定した（写真4）．症例 No. 24 は，皮島を二分割 し口腔内と口腔外の欠損を同時飞再建した（写真 5 ). 胸部の切開線は初期には頸部郭清のための切開線より皮 島部分まで連続させていたが（写真 6 C)，その後 D-P 皮弁の温存や審美性を考慮し皮島の周囲と補助的な切開 線にとどめている(写真 5 D). 症例 No. 7 は鎖骨を一 度離断後 pedicle の基部を鎖骨下に通した（写真 6 B ).

口腔内再建部位をまとめると，舌・古底・下顎齿肉の 再建が19例と半数を占め, 舌 - 口底・下顎荬肉とともに 煩粘膜や咽頭・軟口蓋の一部も含めて再建した症例が 6 


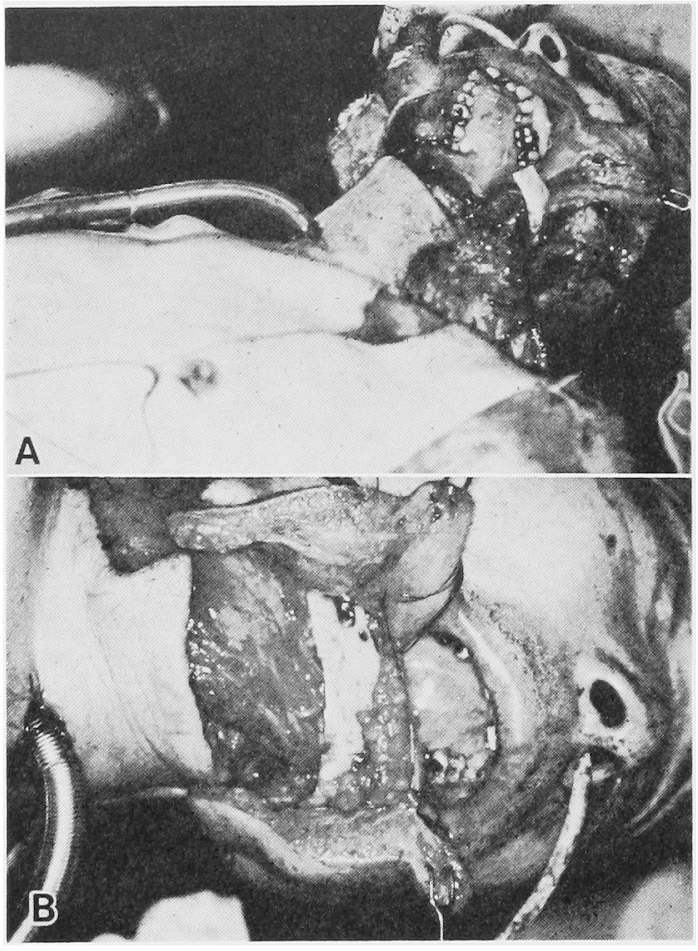

写真 3 症例 No. 15

$\mathrm{A} ：$ 大胸筋皮弁の採取デザイン

B：口底の再建々煮沸下䫑骨の再移植

例，上罘齿肉・軟口蓋咽頭側壁を中心に再建した症例が 4 例, 舌 - 口底・咽頭側壁を再建した症例が 3 例, 下顎 歯肉を中心再建した症例が 8 例で，40例中，喉頭を全 摘出した症例は 1 例（No. 23）のみであった（写真 7 B).

舌の切除範囲についてみると可動部側方切除が 9 例, 可動部前方切除 4 例，可動部全切除 3 例，舌根を含む側 方切除12例, 全摘 1 例, 舌根の一部だけを切除した症例 1 例で，残る10例は非切除であった。

口腔内の切除とともに頸部や顔面の皮膚を切除し再建 した症例は11例で，大胸筋皮并を二分割し口腔内ととも 几再建した症例が 2 例 (No. 24，27)，腹直筋上まで延 長した大胸筋皮弁により舌・底・晨まで連続して再 建した症例方 1 例（写真 4）（No. 5)，大胸筇皮弁に加 え D-P 皮弁を用いた症例 2 例（No. 11，23），遊離の全 層植皮分 2 例（写真 8)（No. 4, 35)，局所皮弁か 1 例 (写真 9) (No. 18)で, 残る 3 例は単純縫縮を行った。

下䫇骨の切除は34例に行い，区域切除が16例，辺縁切 除が 18 例であった（表 3). 下顎を切除した症例中 4 例 は肋骨付き大胸筋皮弁（写真10C）を用い（No. 1，2， $3 ， 4 ， 8$ )，3 例恃避離の腸骨移檤 (写直6 B) (No. 6, 7，21），1 例は者渄下䫇骨の再移植によって再建した

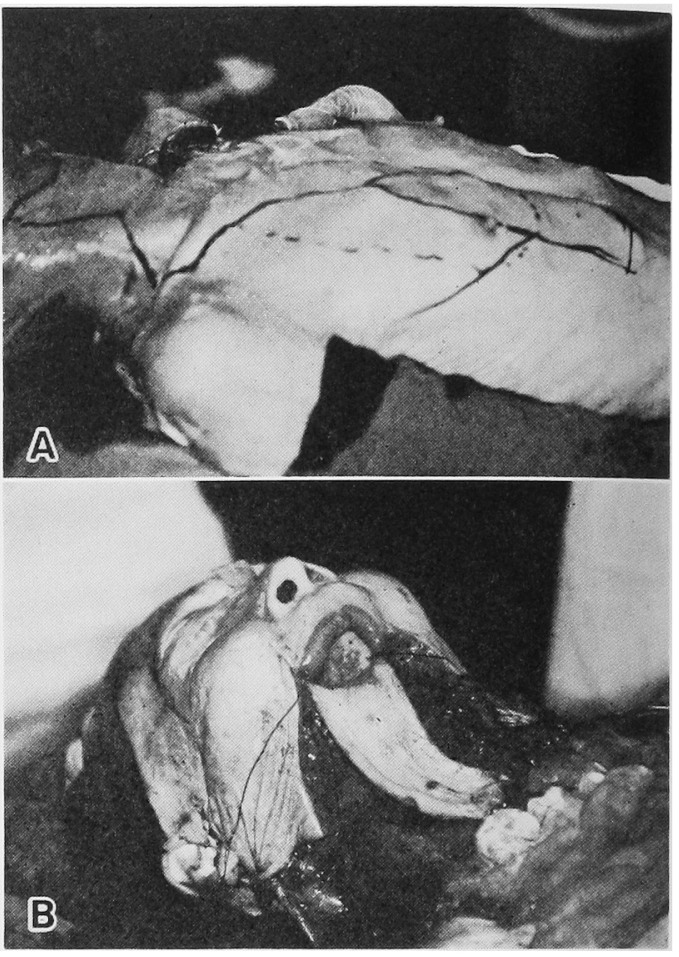

写真 4 症例 No. 5

$\mathrm{A}$ ：大胸管皮弁の採取デザイン

B：皮弁に上る口腔内, 外の再建

（写真3 B ）(No. 15)。 またA-O 靧骨プレートルより下 䫇の形態を保持した症例が 4 例 (No. 10，11，17，29), 鋼線を用いた症例が 2 例 (No. 24，27)，残る19例中， 辺縁切除を施行して再建を行わなかった症例が15例，区 域切除を施行したにもかかわらず再建を施行しなかった 症例が 4 例 (No. 5，9，23，34）あった。手術時の择管

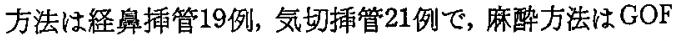
5 例，GOE 29例，GOE+NLA 6 例であった，手術時 間は平均 11.5 時間で，経奥挿管で手術を施行した19例の 平均では10時間であった。出血量は最大 $8,100 \mathrm{ml}$, 最小 $800 \mathrm{~m} l$, 平均では $2,092 \mathrm{~m} l$ であった.

\section{併用 療 法}

一次症例21症例中, 術前化学察法を行わなかった症例 は4 例，CDDP を中心とした化学療法を行った症例が 8 例，PEP を中心とした化学療法を行った症例が 9 例 であった，症例 No. 26 以降の症例では二次症例す含め 原則として術前に CDDP・PEP・VCR によるいわゆる COP 療法 1 から 3 クール計 11症例に施行した。一次 症例中，術前照射を行わなかった症例は11例，二次症例 も含め COP 療法を施行した10症例では術前照射40から 

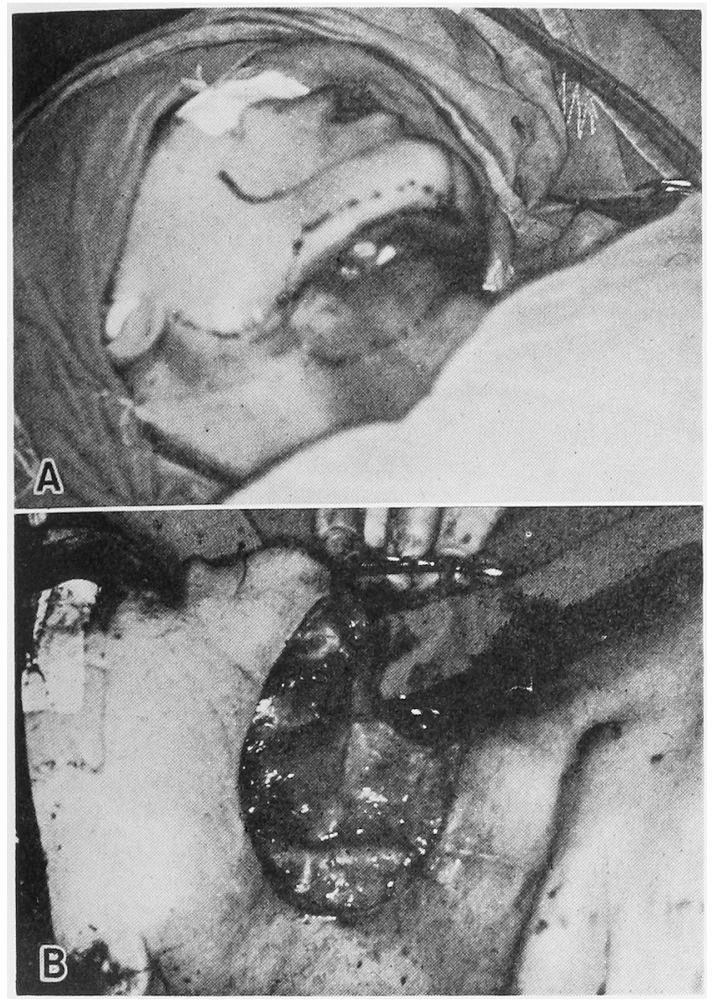

写真 5 症例 No. 24
A : 口腔外の切開線
B : 尰瘍の切除後の口腔内, 外の欠損

$70 \mathrm{~Gy}$ を行った，二次症例，婴髄炎症例の術前までの総 照射楾量は外照射，組織内照射を含め最大 $250 \mathrm{~Gy}$, 平 均虾よそ $100 \mathrm{~Gy}$ であった。一次症例の照射終了から手 術までの期間は最短では 1 日, 平均 28 日, 通常 1 か月以 内に行われた，術後照射は術前 COP 療法, 術前照射を 施行した症例を中心に 40 から $50 \mathrm{~Gy}$ ，計 14 症例に行。 た.

\section{結}

果

\section{1. 術後管理と術後経過}

術後に主たる栄荃管理を中心静脈栄荃で行った症例が 18例，経管栄養22例であった。

術前に気切を行った21例のらち，死亡時まで閉鎖がで きなかった 6 症例を除く 15 症例の平均気切期間（気管力 ーニーレ使用期間) は 31 日で, 最短 8 日, 最長では 154 日を要したが，大部分の症例が 1 か月以内に閉鎖可能で あった，経奥插管により手術した19症例中，3例は術直 後に拔管し，他の16例は術後 1 日から5 日の間に技管し た. しかし 1 例忹抜管直後に呼吸困難を生し，緊急気管 切開を施行した。 入院期間は最短 31 日，最長 439 日で，

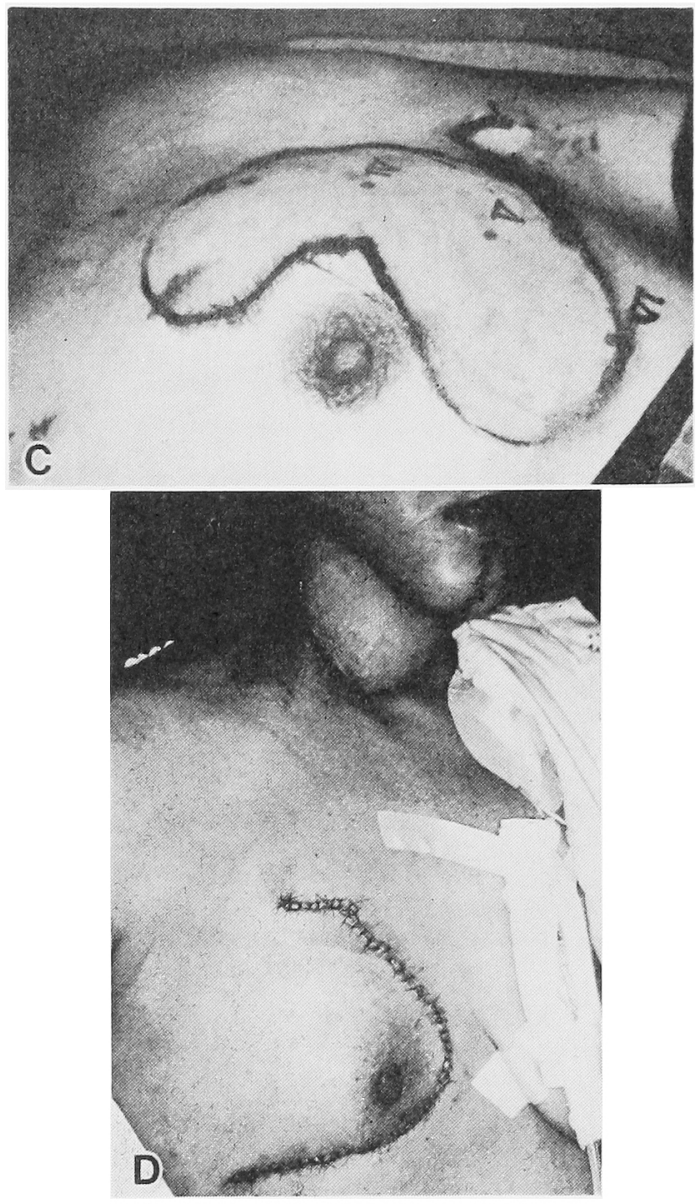

写真 5 症例 No. 24

C：大臉穊皮弁の採取デザイン $\mathrm{D}$ : 再建㣞

平均 3 か月を要した。

筇皮分の術後経過唍全生着 22 例, 縫合不全 6 例, 辺 縁壊死 9 例, 部分壇死 3 例で全壞死の症例はなかった （表 3)，完全生着を除く18例中皮膚口腔瘦孔を形成した 症例は13例で，洗浄や蛍爬再縫合によって 1 か月以内に 治癒した症例が 8 例，D-P皮异によって再再建手術を施 行し，閉鎖までに 3 か月を要した症例が 1 例 (No. 27), 死亡時まで閉鎖しなかった症例が 4 例あった（No. 10， $11,12,15)$.

感染や瘦孔形成のため A-O 䫇骨プレートを除去した 症例が 3 例 (No. 10,11, 29), 鋼線の除去 (No. 27), 肋骨の摘出 (No. 3), 者沸再移植骨の摘出 (No. 15) が 各 1 例あった。瘦孔の形成はもっとも早かった症例 (No. 25）で術後 6 日，遅かった例 (No. 12) では術後44 日 で，通常1ないし2 週間の間に形成された。

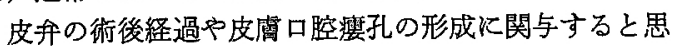




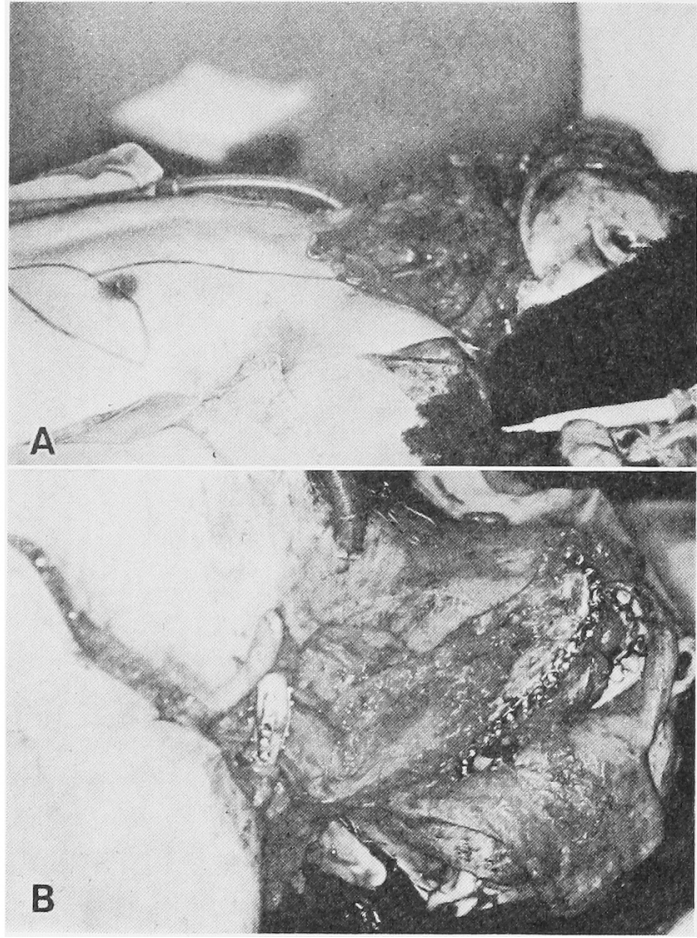

写真 6 症例 No. 7

A：大胸筋皮弁の採取デザイン

B：皮弁基部を銷骨下に通し口腔内を再建

われるいくつかの因子について，掼孔を形成した13症例 と形成を認めなかった 27 症例で，区別して示した（表 了）。それらの因子は, 皮弁の術後経過, 平均年龄, 既往 歴, $\mathrm{T}$ 分類, 術前照射の有無, 術前総照射線量, 下顎再 建方法, 出血量, 単位時間あたりの出血量で, 要的すれ ば，辺縁もしくは部分的な壞死を生じた12症例中，皮膚 口膑掼の形成に至った症例は 7 例であった。平均年齢は

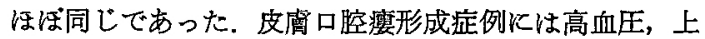
部消化管潰瘍，糖尿病の既往疾患を持った患者が多数認 められた. T3，T2 の 7 症例中 1 例のみに瘦孔形成を認 めた。術前比放射線照射が行われていた27症例中，漤孔 形成を認めなかった16例の平均総照射線量は $65 \mathrm{~Gy}$ ，皮 膚口腔瘦を形成した11例では $110 \mathrm{~Gy}$ であった，下影骨 を切除せず軟組織のみの切除再建を施行した 6 症例に， 嚓孔の形成恃認められなかった（表了）.

その他の術後合併症としては一時的な GOT, GPT 值 の上昇から肝機能障害が疑われた症例が 8 例，肝炎 2 例, 肺炎 7 例, 腎機能障害 3 例, ストレス性胃溃湯, 鎖 骨骨折が各 1 例認められた。

\section{2. 郝後機能}

術後, 食物摄取機能と会話機能を日常生活の状態から 4 穆頪に分類した。食物摄取機能汇関しては，A；固形
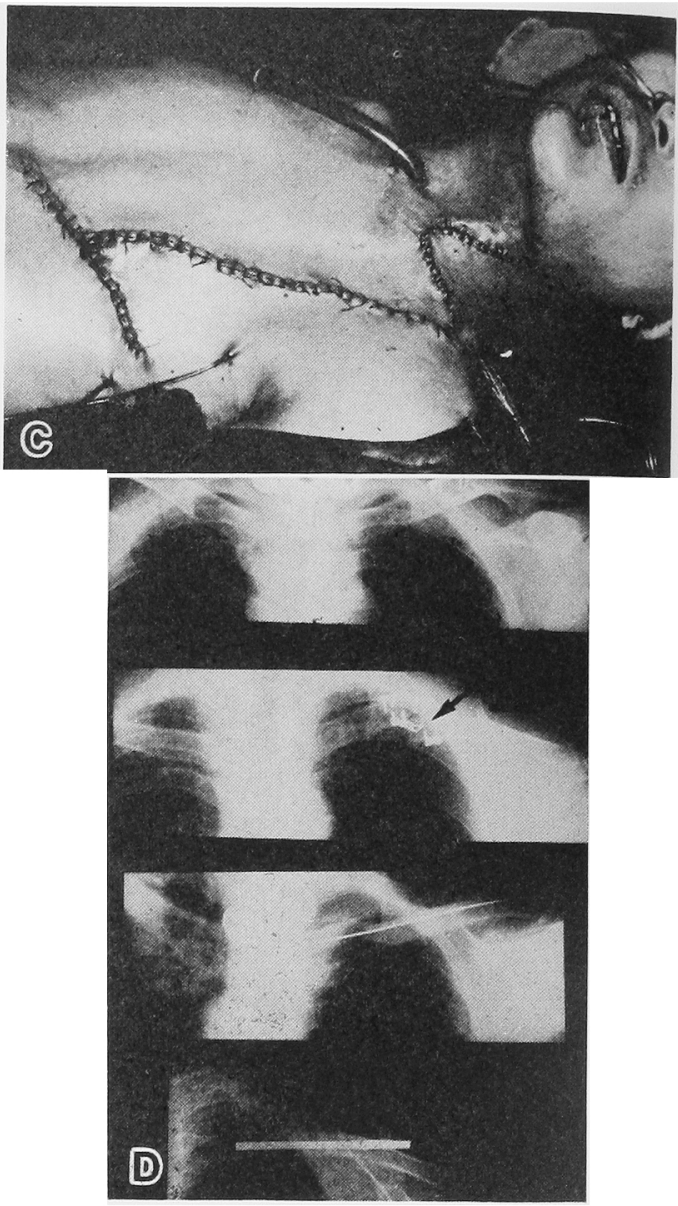

写真 6 症例 No. 7

C : 再建後

D：術後鎖骨のX線所見

プレートの破折(知印) と銅線による再整復固定

食子経口摄取可能 18 例, B ; 流動食を経口摄取可能 12 例， C ; 経口摄取可能だが誤燕しやすく経管栄着を併用 している 4 例， D ; 経口摄取不可 6 例. 同様䚾日常会話 機能に関しては，A；日常生活にはとんど支障がない24 例， B ; 会話に上る意志の踈通が可能10例，C；会話に 上る意志の踈通はきわめて困難 1 例，D；発声不可能 5 例であった，食物摄取機能，日常会話機能ともにAもし くはBであった症例は30例，どちらかがCもしくはDで あった症例は 4 例，両機能ともにCもしくはDであった 症例が 6 例で, 現在生存中の症例に限れば，全例両機能 ともにAるしくはBである(表 4).

その他の術後の機能障害や合併症として筋皮弁の pe-

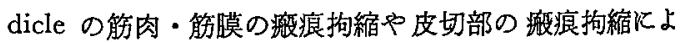
る運動障害を訴兄た症例が 6 例, 筋皮升採取側の局の疼 痛, 運動障害 3 例, 下買骨辺縁切除例に括计る骨片の偏 

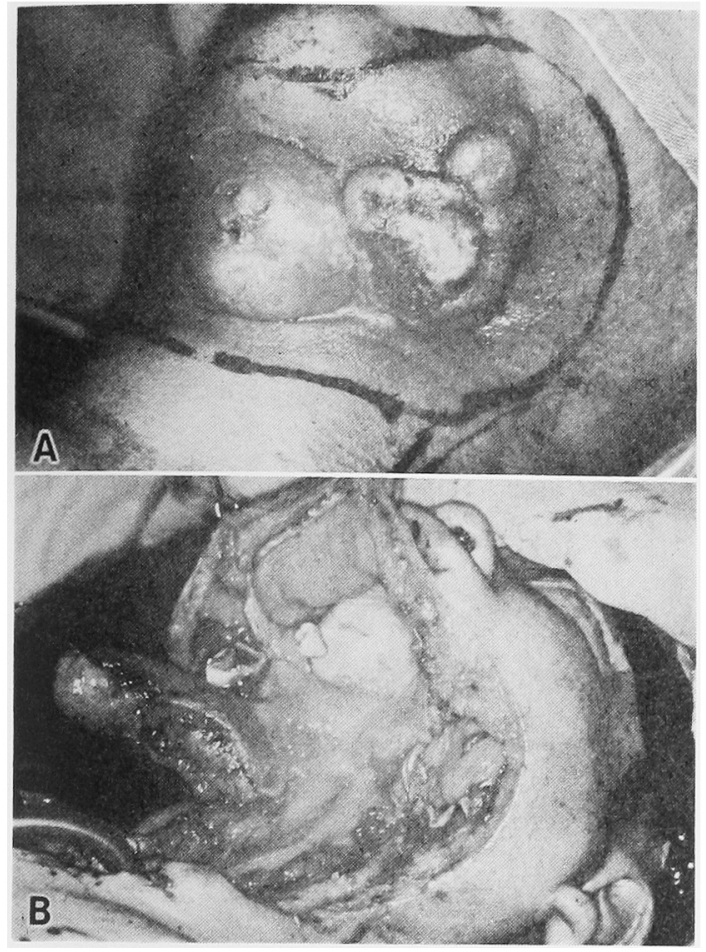

写真 7 症例 No. 23

A : 口腔外の切開線

B : 挋瓷切除後の久損

位や病的骨折，固定に用いたプレートの偏位や動摇が 7 例，流涎 3 例などが認められた。

\section{3. 転 帰}

1988年12月現在, 生存症例恃 22 例, 死亡症例は 18 例 で, 生存者の生存期間は最長 68 か月, 36 力月以上が 8 例, 12 か月以上 36 か月末満が 8 例， 12 か月末満が 6 例であ る. 死亡18症例の生存期間は平均 9 か月, 最短 1 か月で (No. 10)，全例24か月以内に死亡し，12か月末満が12症 例，12か月以上24か月未満が 6 例であった（表 4).

死亡原因は，局所ないし頸部転移巣の再発死が12例， 遠隔転移死 3 例, 嚥下性肺炎 3 例 (No. 10, 16, 33) て あった。 二次症例18例の内, 死亡例が13例, 一次症例21 例中死亡例は 5 例で，内 2 例は他病死 (肺炎)であった。

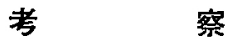

1. 皮弁の壊死, 繸合不全, 皮昆口腔瘦の原因について

即時再建手術後の皮凮口腔漊の形成は, 頻度の高い重 要な合併症の一つである，その形成過程を考学ると，皮 弁の部分的ない儿辺縁部の壊死や，皮弁と口腔粘膜との 繾合不全を契機として手術創部の感染を招き，出液や 膿の貯留を認め，やがて㿉孔が形成される症例が多い。
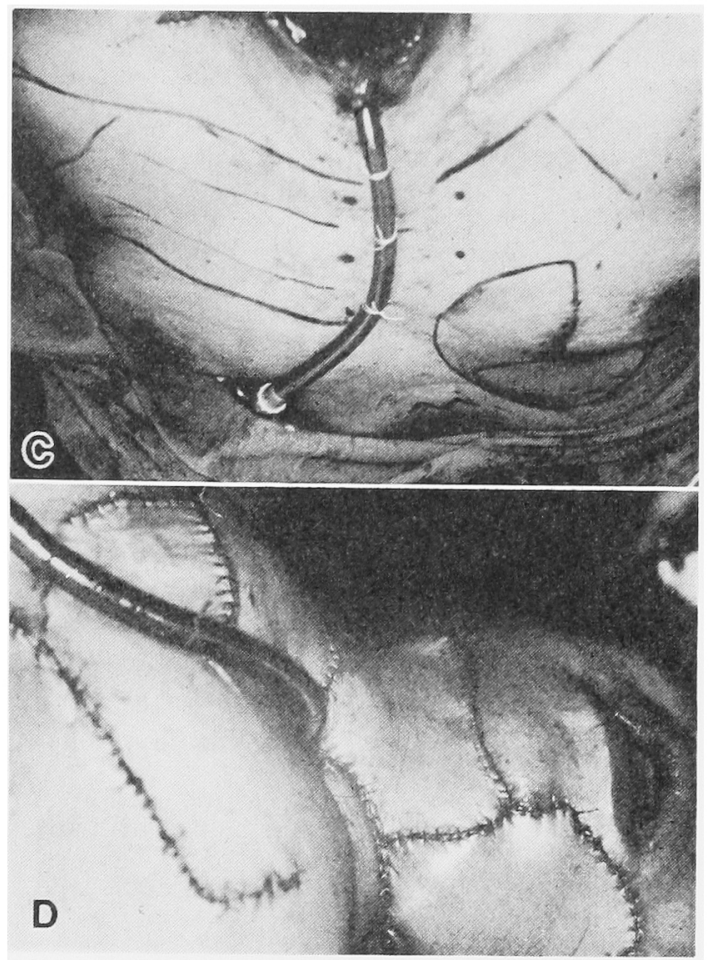

写直 7 症例 No. 23

C : 大胸筋皮弁と D-P 皮弁の採取デザィン D：街後

大胸筋皮弁に批いて皮盧口腔湾の発生頻度は，比較的多 数例の報告を行っている諸家の報告によれば, Beakら は75例中 20 例 (35\%), 工藤ら ${ }^{5}$ は10例中 2 例 $(20 \%)$,

上田 $5^{6)}$ は 19 例中 3 例 $(16 \%)$ ，矢島 $5^{7}$ 《 13 例中 2 例 $(15 \%)$, 早津 $5^{8)}$ は 12 例中 4 例 $(33 \%)$, 著者らの症例 では40例中13例 (32\%) であった．軽微な皮异の壊死や 縫合不全を含めると Schuller ${ }^{9}$ は 49 例中 21 例 (43\%)， Mehrhof $5^{10}$ 江 67 例中 36 例 (54\%), 工藤 ${ }^{5}$ は 10 例中 5 例 $(50 \%)$, 上田 $5^{6)}$ は 19 例中 6 例 $(32 \%)$, 堀越 $5^{11)}$ は33例中 12 例 $(36 \%)$, 著者らの症例では 18 例 (45\%) であった．大胸筋皮弁は，一般に豊富な血行を有し安全 な皮弁の一つと考えられているが，完全な生着が決して 容易でないことが示されている。

皮弁の一部に壊死を生じたり，瘦孔が形成されたとし ても，残存下䫑骨や移植骨さらには固定に用いた金属プ レートやワイヤーに感染が及ばなければ，筋皮升の特徽 とされる旺盛な肉芽形成により，局所洗浄や簡単な强 爬，再綎合処置によって比較的早期に治瘾することが多 い．ただしその間，経口摄取は遅れ入院期間も延長する ことになる．移植骨や残存下顗骨さらにはそれらの固定

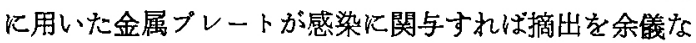
くされ，新たな皮升，筋皮弁による再建手術が必要とな 


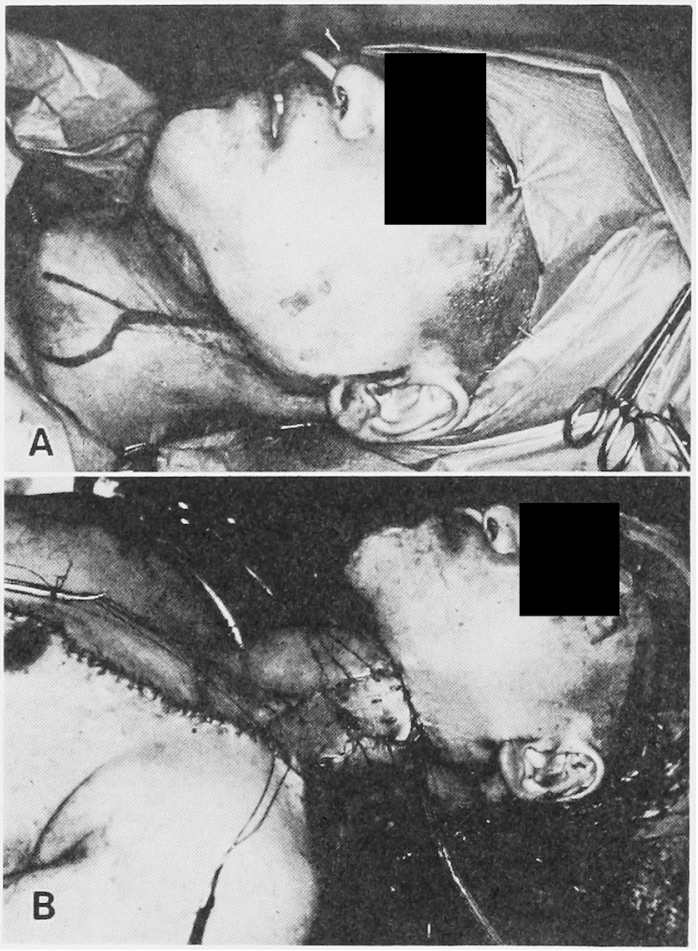

写直 8 症例 No. 4

$\mathrm{A} ：$ 口腔外の切開線

$\mathrm{B} ：$ 遊離皮唐移植による頙部の再建

ることもある．再再建手術を施行しても再び濩孔を形成 するよらな症例では，閉鎖はきわめて困難なことが多 い.

皮弁の壞死や縫合不全, 感染や渡孔形成の原因につい て，著者らの経験に諸家の報告を加えて検討した。

1）手術手技：筋皮弁に対する要護的な取扱はいらま でもない，皮島部切開を真皮までは垂直に，皮下は外側 に向け斜めにいれること，皮島に対し皮下組織面積を可 及的に大きめにとること，皮弁挙上時隹筋肉と皮下組織 の制離を防ぐために，皮島を数か所下部の筋組織に固定 することなどは，基本的な配慮である。

释合時に最も注意すべき点は，皮弁と残存口腔战莫と の過緊張を避けることと思われる $5,7,11)$ ，野間ら ${ }^{12)}$ は皮 弁基部を血管柄のみとし鎖骨下を通すことによって良好 な結果を得たことを報告している，われわれも 1 例 (No. 7）同様の方法に上り皮弁に関しては良好な結果をらる ことができたが，いったん鎖骨を離断したためプレート により固定したにもかかわらず，術㷋偽関節を形成し た.

皮島の大きさの設計は，周囲皮简より切離後化生じる 皮弁面積の収縮分を考慮して設定することも緊張なく縫 合するのに必要と思われる4,5).
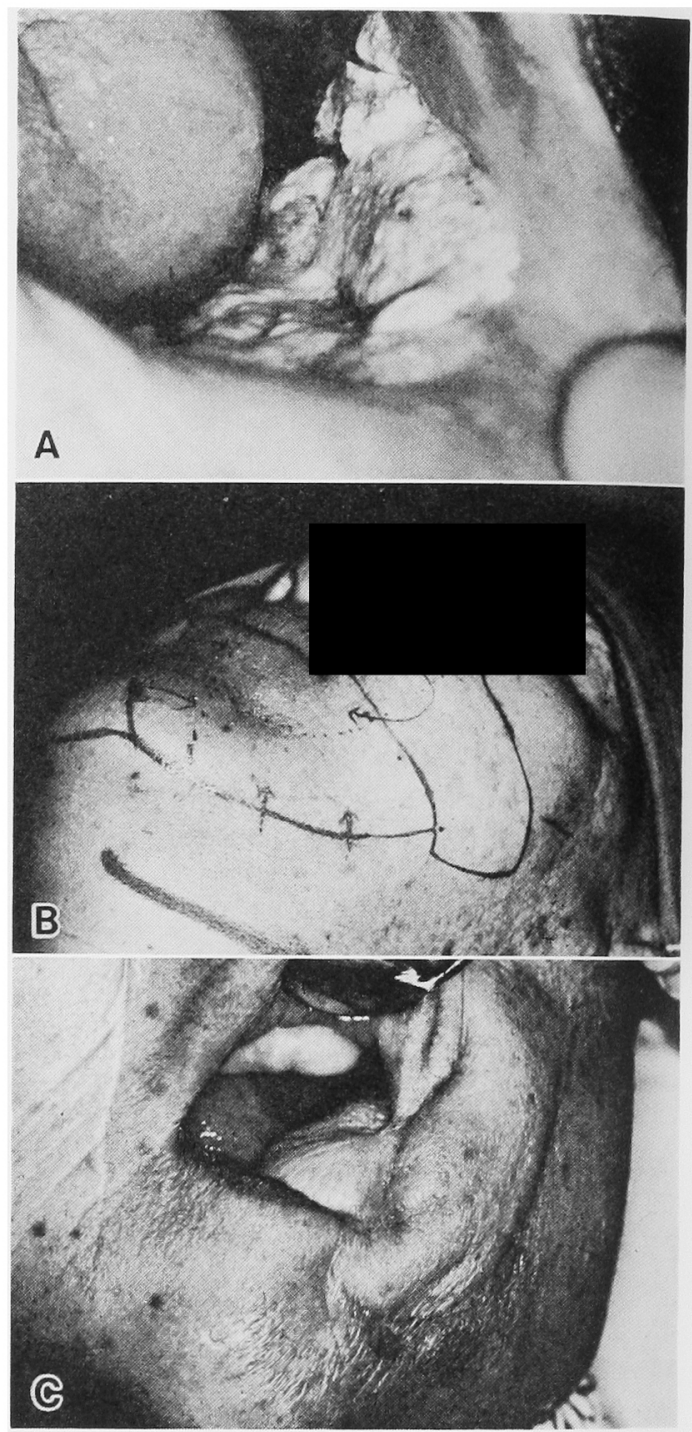

写真 9 症例 No. 18
A：行前口腔内所見
B：口聜外久損を再建する局所皮弁のデザイン
C : 很後

無歯影の場合, 皮弁と口腔粘膜との縫合が概して容易 である。これは歯が存在するために十分な縫い代をとる ことが困難でしかる可動性の乏しい舌側付着歯肉との路 合が回避されることが理由の一つと思われる. 上田ら は皮弁と口腔粘膜との縫合を低位絴合と高位綘合に分類

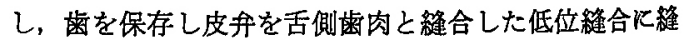
合不全が発生しやすいことを報告している。齿の保存は 術後の機能や補経処置汇重要たが，舌側歯肉と皮升の縫 合には細心の注意を必要とする。

丽気メスによる筋肉の切除恃筋肉の異常な収縮を喚起 


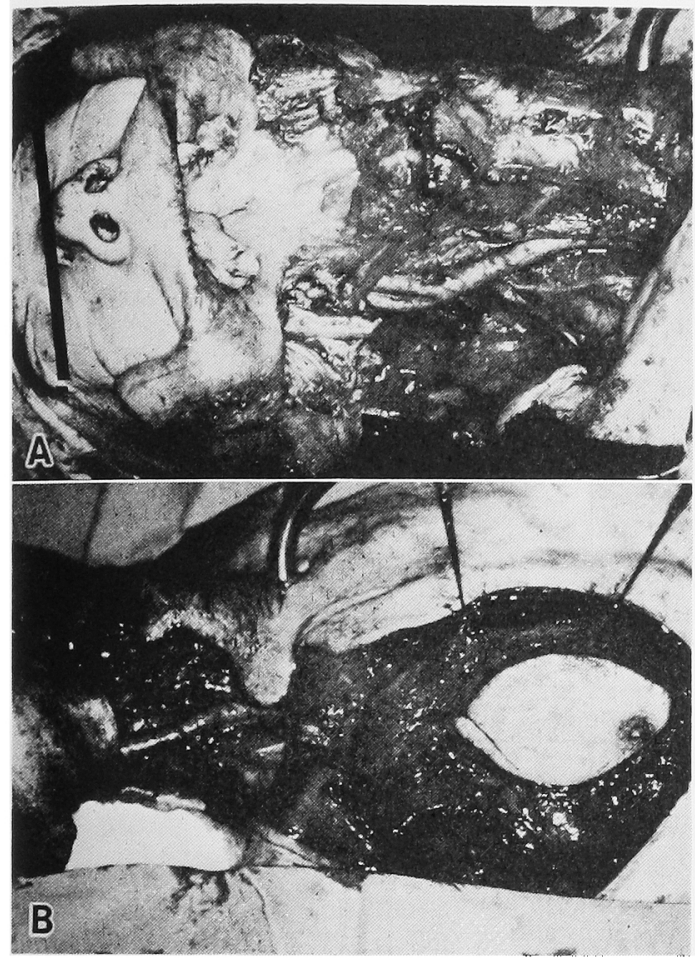

写直 10 症例 No. 1

$\mathrm{A}$ : 畽癔切除後の欠損

$\mathrm{B}$ ：大胸笳皮弁の挙上

し血管や組織の損傷の原因となるため，その使用を避け るとの考学がある゙。かて現在のところ，電気メスが 切離部よりはなれた皮弁の血行などにどの程度の影響を 与兄るかは不明である。電気メスによる切除の最大の利 点はその止血効果にある。メスによる切開では筋肉内の 血管は切除時に筋肉の収縮にともなって，その断端部が 筋肉内に引き込をれるために，完全な止血には注意を要 する. 不十分な止血は術後筋肉内の血腫形成の原因とな り，血腫恃皮弁の血行を障害し，また感染の原因とな る11. 筋皮弁作成時に括ける筋肉の切除方法は，レーザ 一メスの使用なども含め今後さらに検討を要する課題の 一つと思われる。

再建部位が舌口底下影歯肉から軟口蓋や咽頭に及ぶ場 合，口腔内で皮弁が屈曲し上靧部分が循環不全に陥り， 塙死に至ることがある(No. 29)，乙かも形態，機能の 面から舌・立々軟口蓋・咽頭では皮升に求められる要 件が異なる，舌・口底は口底を高く維持するために，大 胸筋皮茾のようなボリニームのある皮弁が求められるの 飞対し，軟口蓋・咽頭では可動性之複雑な欠損形態良

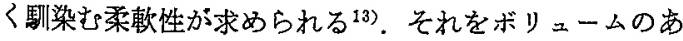
る単一の皮弁により再建することには問題があり，今後 一層の工夫改善が必要と思われた。
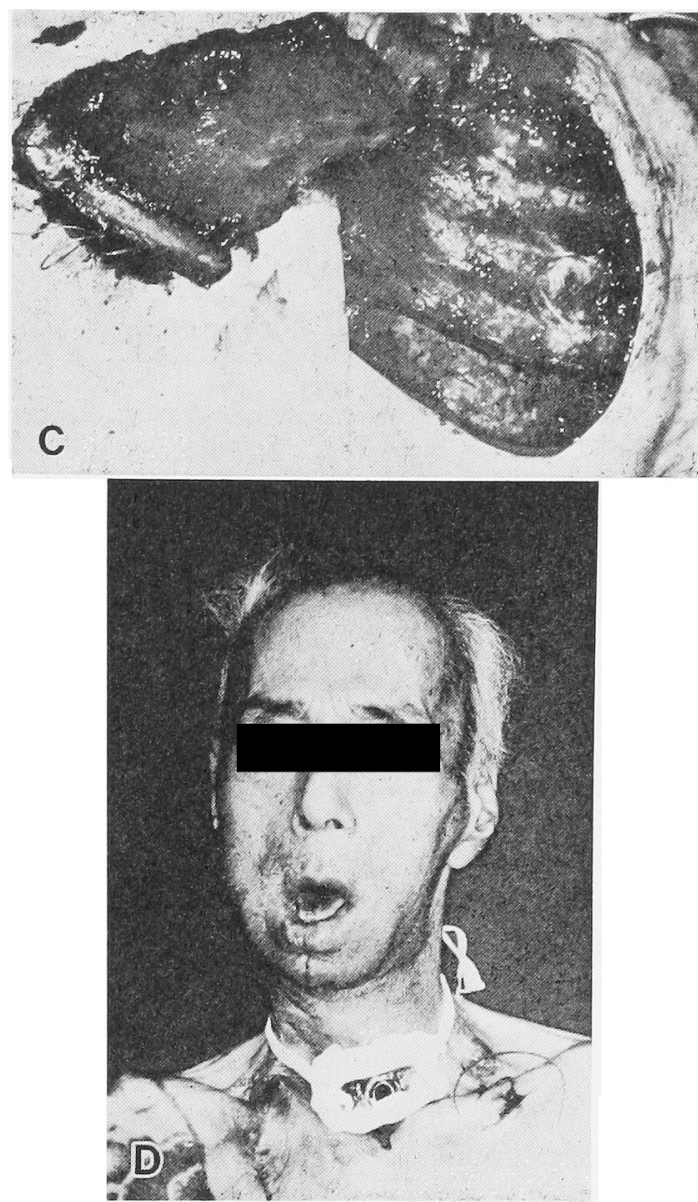

写真 10 遈例 No. 1

C：下顎再建のための第 5 助骨

D：術後顔貌

2）皮弁のデザイン: 手術に際して細心の注意を执っ ているにるかかわらず，前述のごとく完全な生着が容易 でないことから，島状皮弁として用いた大胸筋皮弁が， 安全で確実といわれるだけの豊富な血行を確かに有して いるのかどらか，胸部皮夙の血行形態の解剖学的根拠に 基づいて再考する余地があると思われた ${ }^{14)}$ ．大胸筋皮弁 の主たる血行は肩峰胸動脈に依存し，あたかも血行的汇 は一定の支配領域を持つ direct cutaneous artery 様の 栄荃血管が存在する主軸血管型の皮弁としてとらえられ がちである $3^{5,15)}$ ．乙かしながら近年の皮简血管系の詳細 な観察 ${ }^{(6 \sim 18)}$ 火より，胸部乳頭内側の皮店には，明確な支 配領域を持った肩峰胸動脈由来の皮膚枝ない乙終末枝は 少なく，同部の主たる血行恃，皮弁作製時比断されて しまう内胸勘脈からの anterior perforating branch $飞$ 依存することが知られている。それ穴かかわらず島状 皮弁として用いることが可能な理由は，同血管と肩峰胸 
表 3 皮膚口腔瘦形成症例と非形成症例の比較

\begin{tabular}{|c|c|c|c|c|}
\hline & & $\begin{array}{c}\text { 皮箐口膑瘦 } \\
\text { 形成症例 } \\
\text { 13例 }\end{array}$ & $\begin{array}{c}\text { 非形成症例 } \\
27 \text { 例 }\end{array}$ & 全 症 例 \\
\hline \multirow[t]{4}{*}{ 皮弁䧃後経過 } & 生着 & 0 & 22 & 22 \\
\hline & 縫合不全 & 6 & 0 & 6 \\
\hline & 辺縁壊死 & 4 & 5 & 9 \\
\hline & 部分壊死 & 3 & 0 & 3 \\
\hline \multicolumn{2}{|l|}{ 平均年齢（歳） } & 60 & 59 & 59 \\
\hline \multirow{6}{*}{$\begin{array}{l}\text { 全身的合併症 } \\
\text { ないし } \\
\text { 既往歷 }\end{array}$} & 特記事項なし & 3 & 17 & 20 \\
\hline & 高血王症 & 5 & 2 & 7 \\
\hline & 消化管潰瘍 & 4 & 0 & 4 \\
\hline & 糖尿病 & 2 & 1 & 3 \\
\hline & 結核 & 2 & 2 & 4 \\
\hline & その他 & 2 & 8 & 10 \\
\hline \multirow[t]{4}{*}{$\mathrm{T}$ 分類 } & (二次症例) & 8 & 10 & 18 \\
\hline & $\mathrm{T} 4$ & 4 & 10 & 14 \\
\hline & $\mathrm{T} 3$ & 0 & 4 & 4 \\
\hline & $\mathrm{T} 2$ & 1 & 2 & 3 \\
\hline \multirow[t]{2}{*}{ 術前昭射線量 } & 無 & 2 & 11 & 13 \\
\hline & 有 (平均 Gy) & $11(110)$ & $16(65)$ & $27(83)$ \\
\hline \multirow[t]{3}{*}{ 下顎骨切除 } & 非切除 & 0 & 6 & 6 \\
\hline & 辺縁切除 & 6 & 12 & 18 \\
\hline & 区域切除 & 7 & 9 & 16 \\
\hline \multirow[t]{6}{*}{ 下顎骨再建法 } & 助骨付き筋皮弁 & 1 & 3 & 4 \\
\hline & A-O 顎骨プレート & 3 & 1 & 4 \\
\hline & 鋼線 & 1 & 1 & 2 \\
\hline & 煮沸骨再植 & 1 & 0 & 1 \\
\hline & 遊離腸骨 & 0 & 3 & 3 \\
\hline & 非再建 & 7 & 13 & 20 \\
\hline \multirow[t]{3}{*}{ 出血量 $(m l)$} & 最大 & 8,100 & 4,500 & 8,100 \\
\hline & 平均 & 2,854 & 1,726 & 2,093 \\
\hline & 単位時間当り & 232 & 153 & 179 \\
\hline
\end{tabular}

動脈由来のわずかな穿通枝との間に皮下血管網が形成さ れているためである. Ariyan'2,3) の原法に基つ゚いてデザ インした大胸筋皮弁が，この上らに乱軸血管型の皮弁に 近い性格をるつとすれば，この筋皮弁の血行は従来考兄 られているよりも不安定で, 個人差も少なくないとの認 識が必要となる。早津 $5^{8)}$ も皮弁壊死の原因の一つとし て，採取部位が正中側飞設定された場合をあげている. Ariyan $\left.{ }^{2}, 3\right)$ の原法飞準じ，局甲骨肩峰突起と胸骨剣状突 起を結ぶ線を基準にデザインすると, 皮弁は血行の不安 定な正中側作位しやすい，著者らも当初は原則として Ariyan ${ }^{2,3)}$ の原法に沿って皮弁をデザインしてきたが，
皮痛血行形態の観点からは合理性に乏しく，近年では原 法に捕われることなく, 皮下血管網の温存を優先し, 欠 損の形態に合わせてかなり自由なデザインを行ってい る. 先に述べた皮島之筋肉の固定, 皮䖉切開を外側淌向 けて斜めにいれること, 皮下組織面積を可及的に大きめ にとることは，すべてこの皮下血管網の温存につなが る.

3) 併用療法 : 術前の放射線照射が筋皮弁の術後にど のような影響を与兄るかは, かねてより種々の論議がな されてきた。しかし近年の傾向として放射線照射よる 移植床の変化は皮弁の術後経過影響を与兄ないとする 
表 4 生存症例と死亡症例の比較

\begin{tabular}{|c|c|c|c|c|c|c|c|c|}
\hline & \multicolumn{4}{|c|}{ 生存症例 (22例) } & \multicolumn{4}{|c|}{ 死亡症例（18例） } \\
\hline 一次症例 & \multicolumn{4}{|c|}{16} & \multicolumn{4}{|c|}{5} \\
\hline 二次症例 & \multicolumn{4}{|c|}{5} & \multicolumn{4}{|c|}{13} \\
\hline 骨 艏 炎 & \multicolumn{4}{|c|}{1} & & & & \\
\hline 政後機能 & & & & & & & & \\
\hline 食物摄取機能 & $A=14$ & $\mathrm{~B}=8$ & $\mathrm{C}=0$ & $\mathrm{D}=0$ & $\mathrm{~A}=4$ & $\mathrm{~B}=4$ & $\mathrm{C}=4$ & $\mathrm{D}=6$ \\
\hline 日常会話機能 & $A=17$ & $\mathrm{~B}=5$ & $\mathrm{C}=0$ & $\mathrm{D}=0$ & $\mathrm{~A}=7$ & $B=5$ & $\mathrm{C}=1$ & $\mathrm{D}=5$ \\
\hline \multirow{3}{*}{$\begin{array}{ll}\text { 生存期間 } & \text { 最大（か月） } \\
& \text { 最小（か月） } \\
& 24 \text { か以上(例) }\end{array}$} & \multicolumn{4}{|c|}{65} & \multicolumn{4}{|c|}{22} \\
\hline & \multicolumn{4}{|c|}{5} & \multicolumn{4}{|c|}{1 (平均 9 力月) } \\
\hline & \multicolumn{4}{|c|}{12} & \multicolumn{4}{|c|}{0} \\
\hline
\end{tabular}

\begin{tabular}{|c|c|}
\hline 食牛 & 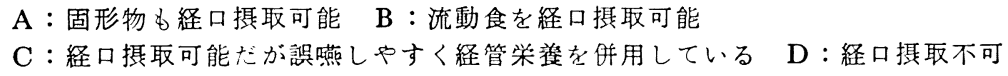 \\
\hline & $\begin{array}{l}\mathrm{A} \text { ：日常生活に注とんど支障がい } \mathrm{B} \text { ：会話による意志の柾通が可能 } \\
\mathrm{C} \text { ：会話による意志の疎通がきわめて困難 D：発声不可能 }\end{array}$ \\
\hline
\end{tabular}

報告が多い6 8)．著者らの40症例の局所，頸部の術前照 射と術後経過の関連をまとめると， $100 \mathrm{~Gy}$ 以上の照射 にかかわらす生着した症例があった。皮弁の壊死や綘合 不全を生じた後に, 創部感染, 難治性の瘦孔形成にいたる 症例之, 旺盛な肉芽形成により治痛する症例があった。 下頭骨の非切除症例に皮夙口腔婓の形成された症例はな かった，皮庙口腔瘦の形成を認めた13例の平均術前照射 線量は $110 \mathrm{~Gy}$ ，形成を認めなかった27例では $65 \mathrm{~Gy}$ で， 以前に $100 \mathrm{~Gy}$ 以上の根治照射がなされた再発 7 症例中 5 例に皮弁の壞死や縫合不全，感染に引き続き，皮䖉口 腔瘦孔の形成を認めた。

以上の結果について考察すると以下のごとくになる。

（a）大胸筋皮弁の生着は移植床に多量の術前照射が加 わっていたとしても可能である。しかし照射による移植 床の変化 ${ }^{19)}$, 特に下顎骨の放射線性骨障害に伴う創傷治 癒能力や感染に対する抵抗力の低下 ${ }^{21 \sim 26)}$ が，なんらかの 原因で皮弁が生着しなかった場合の術後経過に強い影響 を及ぼす。（b） $100 \mathrm{~Gy}$ 以上の照射を受けた症例で皮弁 の壊死や縫合不全を生じると，下䫇骨を含む創部の感染 を招き，難治性の皮夙口腔瘦を形成しやすい。しかし筋 皮弁が完全生着すれば，骨障害の影響を免れることがで きる.（c）照射線量が $100 \mathrm{~Gy}$ 以下か, 下顎骨の非岈除 症例では，比較的その影響は少ない。

骨に放射線性の障害が生じる線量は，70ないし $90 \mathrm{~Gy}$ 以上とされ ${ }^{25,26)}$ ，その発生時期は照射後 1 か月から数年 以上とされている24,28,29)。 したがってわれわれが近年一 次症例に対し施行したように, 術前化学療法とともに40 から $60 \mathrm{~Gy}$ の外照射を行い，照射後 1 か月以内に手術 を施行した場合には，それによって筋皮弁の術後経過が 影響を受けることはほとんどないと考えられる。

術前の化学療法が皮弁の術後経過に影響を与えたとす
る報告はない，われわれの症例においてもそれを示唆す る結果は得られなかった。しかしながら PEP が血管内 皮に及注す影㽬については良く知られており ${ }^{30,31) ， 乙 か ~}$ も化学療法による血管への影響は放射線照射と異なり, 移植床のみに限局しない。また，化学療法の併用は放射 線照射による骨障害を増強するとの報告もある ${ }^{32)}$. した がって今後も注意深い検討が必要と思われる。

4 ）出血量：瘦孔を形成した症例としなかった症例で 総出血量, 時間あたり出血量を比較したところ, 雯孔を 形成した13例の平均出血量は， $2,854 \mathrm{ml}$, 時間あたりの 出血量は $232 \mathrm{ml}$ で,一方, 非形成症例の 27 例ではそれ ぞれ $1,726 \mathrm{ml}, 153 \mathrm{ml}$ であった。全症例 40 例の平均で は総量で $2,093 \mathrm{ml}$, 時間当り $179 \mathrm{ml}$ で, 他の報告 $5,7,8)$ も参考にすれば，腫瘳を切除し大胸筋皮升により再建し た場合，手術時間 10 時間，時間当り $200 \mathrm{ml}$, 総出血量 $2,000 \mathrm{ml}$ といらのが平均的な数值と考えられる. 40 例 中, 時間あたりの出血量が $200 \mathrm{ml}$ を越えた症例は 10 例 で, 内 7 例に皮并の壊死や縫合不全, 創部の感染後に皮 成口腔瘖の形成をみた。総出血量は切除範柬や手術時間 にともない変動するが，単位時間当りの出血量は，手術 手技以外に，血液凝固能，化学療法や放射線照射による 組織障害，骨髄機能の低下など種々の要因に強く影響さ れらる。したがって異常に高い単位時間当りの出血量 は, 術後の管理をより慎重に行らための一つの指摽とな り得る可能性があり, 今後も検討を重ねたい.

5 ）全身的合併症ならびに既往歴：40症例に認めた主 な全身的合併症ならびに既往歴は高血圧症, 上部消化管 潰瘍, 桾疗病, 結核などであった。頭頸部癌患者の既往 疾患は, 高血王, 心疾患, 呼吸器疾患, 消化器潰瘳, 糖 尿病が多くこれは高齡者の多い頭頸部癌患者では当然 の結果とされている ${ }^{33,34)}$. 高血圧症 7 症例中 5 例, 消化 
管潰瘍 4 例の全例, 糖尿病 3 例中 2 例に術後皮虐口腔瘦 の形成をみ, 術後経過が良好であった症例に比べ, いず れも頻度が高かった，従来より糖尿病は，それに伴う血 管の変性や易感染性のために, 皮弁を用いた再建手術に とっては最も注意すべき既往歴の 1 つとされている. 高 血圧症も血管に高度の変性を伴えば，その影響は否定で きない，上部消化管潰瘍に関してはその影響は不明であ る.

\section{2. 呼吸, 栄養管理}

頭頸部領域の広範な切除, 即時再建手術には気道の確 保を目的に全例気切を行らとの考えがある れも当初は手術室において術前に気切挿管を行ったが, 最近では原則として経鼻挿管で手術を施行し, 術後 2 か ら3 日後に抜管することにより, 大部分の症例の呼吸管 理が可能であった.

気切を行えば術後の気道確保は確実たが, 分泌物の吸 引や気管カニューレの交換は煩雑で, しかも気切孔の閉 鎖にかなりの時間を要する症例もある。したがって喉頭 を摘出した症例は当然として, 舌全摘などにより曣下機 能の障害が高度な症例, 下顎骨区域切除後に下顎の再建 を施行しなかったために舌根沈下が確実に予測される症 例を除けば11)，経鼻挿管によって十分管理が可能と思わ れる。たたし抜管後しばらくは呼吸状態の注意深い観察 が必要で, 矢島ら 7 , 工藤ら ${ }^{5)}$ は 5 例中 2 例に抜管後気 切を要したと報告している. われわれも 1 例, 抜管後に 高度の呼吸困難を訴え緊急の気管切開を行った。

術後の栄養管理の方法として, 中心静脈栄養 (IVH) を行わなければならない絶対的な適応症例は少ないと思 われるが, 既往歴で胃の切除を受け, 経管栄荃凧の吸収 に不安のある症例 ${ }^{35)}$ では経管栄養に比べ利点が多いと思 われる

\section{3. その他の全身的術後合併症}

術後頻度の高い合併症は, 肝機能障害, 肺炎で, 頻度 は低いが $\mathrm{DIC}^{5,7)}$ も注意すべき合併症の 1 つと思われ る. 症例 No. 10 では術中より DIC が疑われ総出血量 $8,100 \mathrm{ml}$, 時間当り $675 \mathrm{ml}$ と, きわめて高値を示した. 術後は創部の感染, 肺炎, 敗血症も併発し, 術後約 1 か 月で死亡した. 工藤ら ${ }^{5)}$, 矢島ら ${ }^{7)}$ 術後に DIC を起こ した症例を報告している. 症例 No. 16, 33 では術後経 過は良好で, 腫瘍の再発もみられなかったが, 退院前に 経口摂取を開始したところ德下性肺炎を併発し, 術後 2 から 3 か月で死亡した。與下機能の不安定な患者の経口 摂取の開始に際しては咽頭造影などによる十分な観察が 必要と思われた.

症例 No. 10, 11, 12, 27 では, 肺炎, 手術創部の感 染, きわめて難治性の皮虞口腔瘦孔の形成など種々の合 併症が集中して発生する傾向が認められた。 そのような 症例の多くは二次症例で, 瘦孔や喀痰からは Ps. aeruginosaなどの弱毒菌が分離されることも特徵であった.
このような症例は単に手術方法や創部の局所的な要因た けで説明することは困難と思われた。

一般に担癌生体では非担癌生体に比して免疫応答が低 下しているとされ ${ }^{37)}$ ，さらに外科的処㯰 ${ }^{38 \sim 40)}$, 放射線照 射40 42) による免疫能の 抑制も加わったための感染に対 する全身的な抵抗力の減弱状態が背後にあったと考えら れる. 全身状態がいったんこのような状況に陷ると, 瘦 孔や気切の閉鎖ができず, 経口摄取は遅れ, 入院期間が 長期化する間に腫瘍も再発するという最悪の経過をたど ることもまれでなかった。同様の症例は他の施設からも 報告されている7,8). 現状では術前, 術中, 術後にわた る患者の注意深い観察, 各種の免疫パラメーターによる 免疫能のモニター ${ }^{40,43)}$, 日常臨床における細心の局所, 全身管理の積み重ね以外，こうした症例の発生に対処す る道はないと思われる。

\section{4. 術後機能}

術後の食物摄取機能, 会話機能を患者の生活状態より 4 段階に分類した. 両機能ともに AもしくはBであれ ば，日常生活にほぼ支障はないが，社会復帰のためには 両機能ともにAであることが望まれる. 現在生存中の 23 症例に限れば全例が両機能ともにAもしくはBで, 許容 できる結果であったと思われる。しかし予後不良症例の 中には, 食事の摂取や会話に扣ける高度の機能障害を人 間性の消失と感じ, 精神的苦痛を強く訴えた症例もあ り, 機能的再建の限界と quality of life を念頭に置いた 治療法選択の重要性を感じざるを得なかった。

切除範囲, 特に舌の切除形態と術後機能の関連 ${ }^{44)}$ に関 しては稿を改めて詳細な検討を加えたい.

\section{5. 転 帰}

大胸筋皮弁を含め悪性腫瘍切除後の再建手術に関して 臨床的に検討する際, もっとも重要な観点は, それが治 療成績の向上に寄与しているか否かにあると思われる. 今回検討した 40 症例は, 原発部位は多岐にわたり, また 3 年経過症例で 22 例， 5 年経過症例では10例に過ぎない ため, この問題に関しては今後各原発部位ごとに他の治 療方法も含めて幅広く検討されなくてはならないと考兄 る.しかしあえて現時点で注目すべき結果をまとめる と, 二次症例18例中13例がすでに死亡し，12例が腫瘍死 であったのに対し，一次症例21例では死亡は 6 例で，し かも腫瘍死に限れば 3 例のみであった. 死亡症例の生存 期間は平均で 9 か月と短く, 1 年末満の症例が 12 例で全 例が 2 年以内に死亡した. 以上の結果は, 筋皮弁手術手 技の発達が, 従来手術が困難であった進展症例に対して も外科的切除を可能にしたとはいえ, 再発例では切除、 ーシンンの設定の難しさもあり, 再建を前提とした広範切 除がただちに治療成績の向上に寄与しないことを示して いる．また延命効果からしても，切除が不十分であれば 逆に全身状態の悪化, 腫瘍細胞の広範团な拡散, 早期の 再発と急激な増大を招くために ${ }^{45,16)}$, 術後の平均生存期 
間は短く，大きな期待はもてない.それにもかかわらず 治痛切除の可能性を求め手術に踏み切らざるをえない理 由は，放固すれば予後は必ず不良で，他に変わる有効な 手段がないといらのが現状と思われる。

再建手術のもつ意義は系統的な治療が可能な一次症例 においてより重要である。近年われわれは前述のよ5に $\mathrm{T} 3, \mathrm{~T} 4$ 症例に対し, 即時再建を前提とした広範切除 とCOP 療法 1 から 2 クールの術前化学療法, 40 から 60 Gy の術前外照射と術後照射を組み合わせることを基本 的な治療方針としている．すなわち再建手術の進歩は， 進展一次症例において，十分な安全域をもった抬大切除 を柱とし, 術前, 術後の化学療法, 放射線照射, 免疫療 法よりなる複合療法の確立を可能にした。すでにこのよ らな考えに基ついた複合療法により頭頸部癌の治療成績 に向上がみられたとの報告もなされている47,48). したが って今後, 再建手術により単に従来は切除が困難であっ た症例の外科的治療か，技術的に可能になったといら点 に留まらず，再建を前提に可能となった広範切除を他の 治療法ととのように組み合わせ有効な複合療法へと発展 させるかが， $T_{3}, T_{4}$ 症例の治療成績の向上に重要と思 われる。

なお下顎骨の切除, 再建方法と術後経過の関連 ${ }^{9)}$, 舌 の切除範囲と口腔機能の関連, 術後の経過不良症例に認 められた特有の諸検查所見 ${ }^{49)}$, 術後長期経過症例に生し た問題点や口腔内に移植された筋皮弁皮成の変化 ${ }^{50) な と ゙ ~}$ については稿を改めて詳細な検討を加えたい。

\section{ま と め}

われわれが経験した大胸筋皮弁によるロ腔癌切除後の 即時再建40症例を基に, 局所ならびに全身的な種々の合 併症の発生に関与する各種の要因, 術後管理の方法, 術 後機能について検討を行い以下のような結果を得た。

1 ）大胸筋皮弁の完全生着の難しさは，胸部皮成の血 行形態そのものに起因する場合がある。

2 ) 術前の放射線照射による移植床の変化は大胸筋皮 升の術後経過それ自体に影響を与えないが，大量照射に よる骨障害は術後感染や皮成口腔瘦の形成に二次的に関 与する。

3 ）二次症例では局所的には切除マージンの設定の難 しさと, 全身的には, 術前からの放射線, 化学療法に加 え手術侵襲により極度の免疫能の低下状態に陷る可能性 があり, 再建手術を前提とした外科的治療の改善だけで は治療成績の向上はあまり期待できない。

4）進展した一次症例に対し, 再建手術の進歩は, 広 範切除亡化学療法, 放射線療法, 免疫療法とを計画的に 結びつけた集学的治療を可能にし,今後さらにその発展 が望まれる。

\section{引用文 献}

1）澤木修二：Quality of life からみた頭頸部癌治 療の進歩。癌々臨床 15：2675-2679 1988.

2) Ariyan, S.: The pectoralis major myocutneous flap. A versatile flap for reconstruction in the head and neck. Plast Reconstr Surg 63: 73811979.

3) Ariyan, S.: Further experiences with the pectoralis major myocutaneous flap for the immediate repair of defects from excisions of head and neck cancers. Plast Reconstr Surg 64: 605 $-6121979$.

4) Beak, S.M., Lowson, W., et al.: An analysis of 133 pectoralis major myocutaneous flaps. Plast Reconstr Surg 69: 460-467 1982.

5）工藤啓吾，柘植信夫，他：大胸皮弁に上る口腔 癌切除後の即時再建. 日只外誌 29: 514-521 1983.

6)上田実，糟谷政代，他：舌口腔底再建に用い

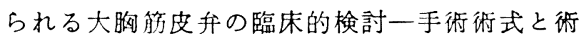
後機能の関連について一 日口外誌 34：106610731988.

7) 矢島幹人, 武田進, 他: 筋皮弁に上る口腔腫 晹切除後の再建 第 2 報大胸筋皮弁及び広背 筋皮少の応用。日口外誌 32：1622-1634 1986.

8）早津良和，鉒崎文彦，他：大胸筋皮弁を用いた 口腔癌切除後の即時再建. 口科誌 37：338-344 1988.

9) Schuller, D.E.: Pectoralis myocutaneous flap in head and neck cancer reconstruction. Arch Otolaryngol 109: 185-189 1983.

10) Mehrhof Jr., A.M., Rosenstock, A., et al.: The pectoralis major myocutaneous flap in head and neck reconstruction. Analysis of complication. Am J Surg 146: 478-482 1983.

11）堀越 勝, 草間幹夫, 他：舌拉よび口底瘦手很 に打ける下顎骨の切除方法ならびに即時再建に 関する研究. 日口外誌 34：1094-1101 1988.

12）野間弘康, 佳々木研一, 他: 頭頙部に応用する 大胸筋皮少作成の一工夫と臨床応用。口科誌 36: 449-456 1987.

13）大野康亮, 吉田広, 他: 遊離前腕皮弁に上る 軟口蓋扣よび口陕咽頭部欠損の即時再建の経 験。日口外誌 34：1729-1737 1988.

14）大村進，川辺良一，他：大胸筋皮弁に関する 臨床的ならびに基礎的研究. I 当科に扣ける大 胸筋皮弁を用いた即時再建 30 症例の検討（抄）. 日口外誌 33：2611 1987.

15）坂東正士：大胸筋を利用した頭頸部の再建法. 手術 36：751-760 1980 .

16) 斉藤 等, 佐藤文彦, 他: 大胸筋皮弁採取部位 の検討。耳喉 56：1003-1005 1984.

17）西條正城：皮店移植一有茎皮度移植の理論 新 
外科学体系 29 巻 A 第 1 版, 中山書店, 東京, 1983，141-159頁.

18）石川好美，川辺良一, 他：大胸筋皮弁に関する 臨床的ならびに基礎的研究. II 色素注入法によ る大胸筋皮弁の血行形態関寸る基礎的研究と 臨床応用上の問題点(抄). 日口外誌 33：261126121987.

19）小谷 朗：放射線口内炎の発生およびその経過 に関する臨床的ならびに実験的研究。口病誌 29: 340-373 1962 .

20）平木神一郎：放射線炤射後の創伤治癋に関する 実験的研究一家鬼の炤射下買骨の脱灰凍結乾燥 骨移植一。 日口外誌 34:845-864 1988.

21) 藤田 實：放射線照射に上る顎骨生涯の初期変 化関する実験的研究. 歯放 27：83-104 1987.

22) Marciani, R.D. and Ownby, H.E.: Osteoradionecrosis of the jaws. J Oral Maxillofac Surg 44: 218-223 1986.

23）藤下昌己：放射線治療による顎骨障害に関する 研究。歯故 20：237-261 1980.

24）岡野篤夫, 加藤讓治, 他: 顎骨の放射線骨障害 に関する臨床的研究。日口外誌 34：1460-1471 1988.

25）奥山武雄, 堀内淳一, 他 : 放射線下顎骨障害 （いわゆる放射線骨壊死）第 3 報 線量時間因 子の検討 (舌癌症例からの分析)。日本医放会 誌 41: 894-903 1981.

26) Morrish, R.B., Chan, E., et al.: Osteoradionecrosis in patients irradiated for head and neck carcinoma. Cancer 47: 1980-1983 1981.

27) Bedwinek, J.M., Shukovsky, L.J., et al.. Osteoradionecrosis in patients treated with definitive radiotherapy for squamous cell carcinomas of the oral cavity and naso-and oropharynx. Radiology 119: 665-667 1976.

28）猪俣泰典, 浜田富三郎, 他：口腔, 咽頭癌の放 射線治療による後障害について。日 癌治 19: 44-49 1984.

29）岡田豊，逢坂文博，他：口腔癌の放射線治療 にともな5顎骨障害について。 日 ロ外誌 30 : 679-685 1984.

30)島岡成和：抗癌物質がラット舌粘膜下毛細血管

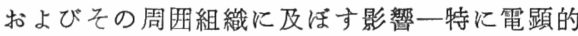
観察について一. 日口外誌 32: 1581-1593 1986.

31）西下 明，木村郁朗，他：腫場および肺の血管 に及ぼす Bleomycin の影響。脈管学 11：23261971.

32) Schwartz, H.C.: Osteoradionecrosis of the jaws: a complication of cancer chemotherapy. Head \& Neck Surg 4: 251-253 1982.

33）作田正義, 墨 哲朗, 他 : 頭頸部癌患者にみら れた全身的合垪症。日口外誌 34：51-55 1988 。

34) 平賀 智, 中村克彦, 他 : 頭頸部覀性腫瘍症例 の治療上の問題となった全身的合併症，頭頸部 腫瘍 11：315 1984.
35）荤村俊一, 山崎正, 他：筋皮弁に上る口腔腫 瘍切除後の再建 第一報 胸鎖孚突筋を茎とし た島状笳皮弁, 島状骨筋皮弁の応用。日口外訰 32: 84-91 1986.

36) 遠藤 豊, 堀本 進, 他: 口腔外科領域に扣け る中心静脈栄峑の検討. 口科誌 37: 99-108 1988.

37) Kamo, I. and Friedman, H.: Immuno suppression and the role of suppressive factors in cancer. Adva Cancer Res 25: 271-321 1977.

38) Kwan, P.S., Brody, J.I., et al.: Immunosuppressive effect of surgery. Lancet I: 53-55 1971.

39）吉野純爾：胃癌患者の非特異的細胞性免疫能に 関する臨床的研究一とくに手術後の変動につい て一. 日外会誌 82: 355-367 1981 .

40) 田辺均, 伊田正道, 他: 頭頸部悪性腫演患者 の免疫学的指標について. 日外誌 33: 2902961987.

41) Stjernsward, J., Jondal, M., et al.: Lymphopenia and change in distribution of human $\mathrm{B}$ and $\mathrm{T}$ lymphocytes in peripheral blood induced by irradiation for mammary carcinoma. Lancet I：1352-1356 1972.

42) Tarpley, J.L., Potrin, C., et al.: Prolonged depression of cellular immunity induced laryngopharyngeal cancer patients treated with radiation therapy. Cancer 35: 638-644 1975.

43）宮田佳代子, 佃守, 他 : 頭頸部癌化学療法 による細胞性免疫能の変動. 痹の臨床 33: 1035 $-10381987$.

44）今井智子, 道 健一, 他 : 舌 ・ 口底切除後の語 音発語明瞭度一切除範囲扎よび手術法との関連 について一。 日口外誌 34：1567-1583 1988.

45) Staab, H.J., Anderer, F.A., et al.: Eightyfour potential second-look operations based on sequential carcinoembryonic antigen determinations and clinical investigations in patients with recurrent gastrointestinal cancer. Am J Surg 149: 198-204 1985.

46) 久保保彦：肝細胞癌の臨床。内科 52: 470-474 1983.

47) 天笠光男, 岩城 博, 他 : 口腔癌即時再建症例の 治療成績と術後機能に関する研究。日癌治 23 : 2591-2597 1988.

48）今野昭義, 藤吉達也, 他 : 口腔癌, 上顎癌に対 する即時再建手術を組み入れた複合療法。遠隔 成績と術後形態捄よび機能評価。癌の臨床 28 : 599-606 1982.

49) 大村 進, 青木伸二郎, 他 : 大胸筋皮弁に上る 即時再建の術中術後の管理に関する検討 (抄). 口科誌 35: 8331986.

50）石川好美，川辺良一，他：大胸笳皮弁に関する 臨床的ならびに基礎的研究. 第 3 報術後 2 年 以上経過した大胸筋皮弁の形態変化 (抄). 口 科誌 37: 11211988 . 